\title{
Baicalein inhibits pancreatic cancer cell proliferation and invasion via suppression of NEDD9 expression and its downstream Akt and ERK signaling pathways
}

\author{
Rong-Tao Zhou ${ }^{1}$, Mei He ${ }^{1}$, Ze Yu' ${ }^{1}$, Yang Liang ${ }^{1}$, Yuzhe Nie ${ }^{1}$, Sheng Tai ${ }^{2}$ and Chun-Bo \\ Teng ${ }^{1}$ \\ ${ }^{1}$ College of Life Science, Northeast Forestry University, Harbin, China \\ ${ }^{2}$ Department of General Surgery, The Second Hospital of Harbin Medical University, Harbin, China \\ Correspondence to: Chun-Bo Teng, email: chunboteng@nefu.edu.cn \\ Keywords: baicalein, pancreatic cancer, NEDD9, AKt, ERK
}

Received: December 21, $2016 \quad$ Accepted:March 06, $2017 \quad$ Published: April 07, 2017

Copyright: Zhou et al. This is an open-access article distributed under the terms of the Creative Commons Attribution License 3.0 (CC BY 3.0), which permits unrestricted use, distribution, and reproduction in any medium, provided the original author and source are credited.

\section{ABSTRACT}

\begin{abstract}
Baicalein, a flavone ingredient of Scutellaria baicalensis Georgi, is a promising anti-cancer agent. However, its potential anti-pancreatic cancer effects and the underlying mechanisms are still unclear. In this study, we showed that Baicalein not only induced apoptosis, but also suppressed proliferation, migration and invasion of two pancreatic cancer cell lines BxPC-3 and PANC-1 in a dose- and time-dependent manner. Notably, Baicalein exhibited low toxicity to normal human liver or kidney cells. We further discovered that Baicalein suppressed BXPC-3 and PANC-1 cell proliferation and invasion through targeting the expression of NEDD9, a Cas scaffolding protein, to decrease Akt and ERK activities. Especially, Baicalein decreased Akt phosphorylation at T-308 via lowering NEDD9-dependent PDK1 expression. Overexpression of NEDD9 effectively rescued proliferation and invasion of BXPC-3 and PANC-1 cells dampened by Baicalein. Taken together, our findings suggest that Baicalein is a potent remedy applied to pancreatic cancer treatment in the future.
\end{abstract}

\section{INTRODUCTION}

Pancreatic cancer, especially the pancreatic ductal adenocarcinoma, is a devastating disease with high mortality and has a 5 -year survival rate less than $5 \%$. Its symptom is relatively latent at the early stage rendering a poor prognosis for the suffering [1]. In most cases, once diagnosed, the cancer has already reached the advanced stages characterized by remarkable aggression and malignancy. In fact, distant metastasis accounts for $90 \%$ death caused by pancreatic cancer, as revealed by clinical inspections [2,3]. Accordingly, the effectiveness of surgical resection therapy for pancreatic cancer is greatly reduced. Chemotherapy and radiation therapy are the supplementary schemes; however, pancreatic cancer cells are highly resistant to the traditional chemotherapeutic agents, such as Gemcitabine [4]. To date, there is still lack of potent and low-toxic medication available for the treatment of pancreatic cancer patients.
Nowadays, plant-derived active components attract more and more attention as they are playing extensive roles in treatment of an increasing number of diseases. Scutellaria baicalensis Georgi, a traditional Asian herb, is widely used in clearing heat dampness and purging fire detoxification. The main active ingredients of this plant are flavonoid compounds, including Baicalein, Baicalin, Chrysin, Wogonin, and Wogonoside [5, 6]. Among them, Baicalein (5,6,7-trihydroxyflavone) is the most attractive component with a variety of pharmaceutical effects, such as antioxidation, antithrombosis, bacteria- and viruskilling properties, as well as inhibition of inflammatory response and allergic edema $[7,8]$.

Notably, Baicalein has recently been discovered for its activity against a wide range of cancers, including breast cancer, prostate cancer, ovarian cancer, bladder cancer [9-13]. Baicalein is also found to repress growth and promote apoptosis of several pancreatic cancer cell lines through blocking the 12-lipoxygenase pathway 
and activating the mitochondrion-dependent apoptotic pathway [14-16]. However, both the detail effects of Baicalein on the pancreatic cancer and the underlying molecular mechanisms are still elusive.

It has been reported that Baicalein can inhibit cancer cell progression through suppressing Akt, MAPKs (ERK/p38), Wnt, and TGF- $\beta$ signaling pathways [17, 18]. Among them, inhibition of Akt signaling leads to decreased phosphorylation of the downstream mammalian target of rapamycin (mTOR) to arrest cell cycle and induce cell apoptosis or autophagy [19-22], whereas ERK signaling suppression results in downregulation of matrix metalloproteinases (MMPs) but upregulation of the tissue inhibitor of metalloproteinases (TIMPs) to reduce cell motility and migration [23, 24]. Therefore, blocking Akt and/ or ERK signaling cascades is an important tactics employed by Baicalein to achieve its anti-tumor activities [25-27]. However, the targets of Baicalein upstream of the Akt and ERK signaling pathways are still understudied.

Neural precursor cell expressed developmentally downregulated 9 (NEDD9), also named as human enhancer of filamentation 1 (HEF1) or Cas-L (Crkassociated substrate L), is a scaffold protein localized in focal adhesions to assemble the focal adhesion kinase (FAK) and the non-receptor tyrosine kinase c-Src to regulate multiple cellular signaling pathways $[28,29]$. NEDD9 is highly expressed in breast cancer, colorectal cancer and head and neck cancer, in which its expression levels are positively correlated to cancer cell migration, invasion, and metastasis [30-33]. Moreover, both mRNA and protein levels of NEDD9 are elevated in pancreatic carcinoma compared with the matched adjacent noncancerous tissues [34, 35]. However, there is so far limited information on NEDD9 as a drug target in pancreatic cancer treatment. In this article, we systematically analyzed the effects of Baicalein on pancreatic cancer development, and explored the role of NEDD9 in Baicalein-affected cell signaling pathways.

\section{RESULTS}

\section{Baicalein inhibits malignancy of pancreatic cancer cells in vitro}

To extensively explore the effect of Baicalein on pancreatic cancer growth and invasion, two distinct types of human pancreatic cancer cell lines, BxPC-3 (pancreatic adenocarcinoma cells) and PANC-1 (pancreatic ductal cancer cells), were treated with increasing concentrations of Baicalein $(0,25,50,75$, and $100 \mu \mathrm{M})$ for different time periods $(0,24,48$, and $72 \mathrm{~h})$. CCK8 measurements showed that Baicalein significantly decreased cell numbers of both BxPC-3 and PANC-1 in a dose- and time-dependent manner (Figure 1A). Incubation of $50 \mu \mathrm{M}$ Baicalein for $48 \mathrm{~h}$ markedly induced cell death of BxPC-3 and PANC1; however, the same concentration of Baicalein exhibited little toxicity to the normal human liver cell line HL-7702 or human embryonic kidney cell line 293T (Supplementary Figure 1A). We then implemented fluorescence activated cell sorter (FACS) analysis via Annexin V-FITC and PI doublestaining to investigate apoptosis of BxPC-3 and PANC-1 cells treated with 50 or $100 \mu \mathrm{M}$ Baicalein for $48 \mathrm{~h}$ (Figure 1B). After excluding dead cells, we could still detect 7.01 $\pm 0.52 \%$ and $11.03 \pm 0.28 \%$ apoptotic cells in BxPC3 and PANC-1 cells, respectively (Figure 1B). Western blotting confirmed that apoptotic promoting proteins Bax and cleaved-caspase 9 were markedly upregulated at $72 \mathrm{~h}$ by Baicalein compared with DMSO treatment (Figure 1C).

In addition to cell apoptosis, cell number decrease caused by Baicalein might also be due to cell proliferation inhibition. Thus, Ki-67 staining was employed to examine the effect of the treatment by $50 \mu \mathrm{M}$ Baicalein for $48 \mathrm{~h}$ on the proliferation of the two cell lines. As shown in Figure $1 \mathrm{D}$ and Supplementary Figure 1B, there were less Ki-67 positive cells in the Baicalein-treated group (14.43 $\pm 1.62 \%$ of BxPC-3, $44.1 \pm 6.09 \%$ of PANC- 1$)$ than in the control $(85.67 \pm 1.17 \%$ of BxPC-3, $73.8 \pm 8.59 \%$ of PANC- 1$)$. FACS analysis further demonstrated that $50 \mu \mathrm{M}$ Baicalein treatment led to $74.64 \pm 1.73 \%$ of BxPC-3 and $59 \pm 2.56 \%$ of PANC-1 cells arrested at G0/G1 phase (Figure 1E and Supplementary Figure 1C). Western blotting indicated that P21 and P27 were both upregulated in Baicalein-treated BxPC-3 cells (Supplementary Figure 1D). We further tested the effect of Baicalein on the colony-forming ability of BxPC-3 and PANC-1 cells. As shown in Figure 1F, there were only a few colonies observed in $50 \mu \mathrm{M}$ Baicaleintreated groups and nearly no colony in $100 \mu \mathrm{M}$ Baicaleintreated groups for both cell lines $(n=3)$.

The effects of Baicalein on the motility and invasion capability of pancreatic cancer cells were evaluated through wound healing assay and Transwell assay, respectively. At $72 \mathrm{~h}$ after BxPC-3 and PANC-1 cells were scratched, the edges of the monolayer cell gaps in the control group had completely merged. In contrast, there were only few cells migrating into the scratched area in the Baicalein-treated group (Figure 1G and Supplementary Figure 1E). In the Transwell assay, based on the number of the cells having migrated to the bottom layer, it could be ascertained that Baicalein significantly inhibited the invasion of both BxPC-3 and PANC-1 cells (Figure 1H). Altogether, the above results showed that Baicalein could not only promote apoptosis, but also suppress proliferation, migration and invasion of the two types of pancreatic cancer cells, thus effectively blocking cancer cell proliferation and invasion in vitro.

\section{Baicalein suppresses Akt and ERK signalings, as well as the expression of NEDD9 in pancreatic cancer cells}

As the activation of PI3K/Akt and/or MEK/ERK is important for the invasion of human pancreatic cancer cells [36, 37], we investigated the effects of Baicalein on these two signaling pathways in BxPC-3 and PANC1 cells. Western blotting results showed that Baicalein 
A

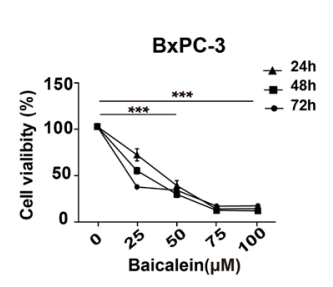

PANC-1

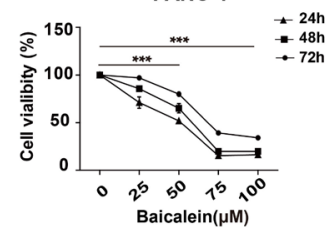

C

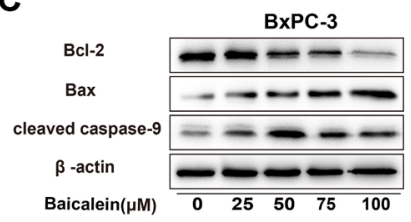

E
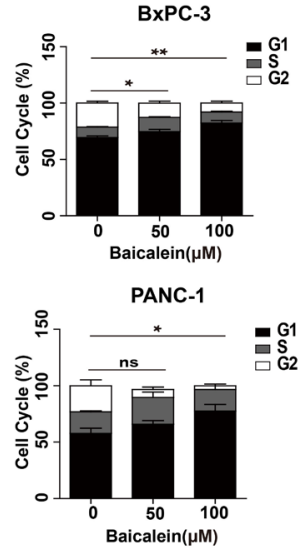

H

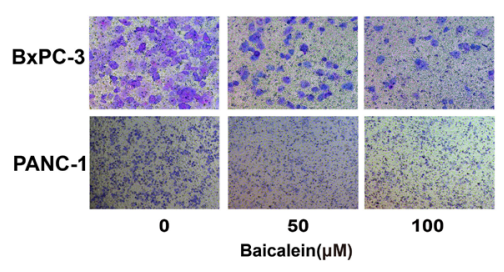

B

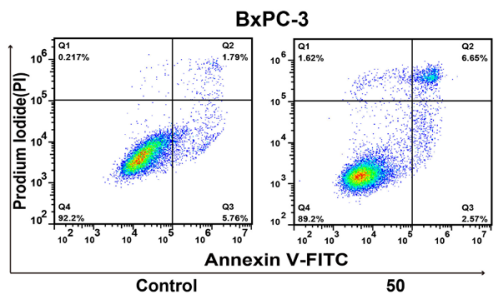

PANC-1

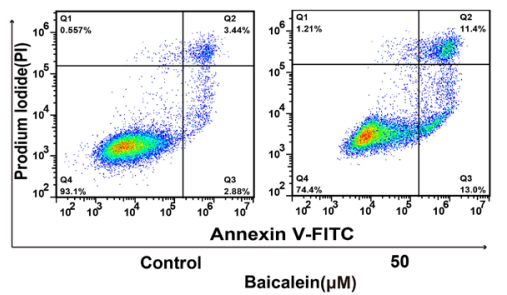

D
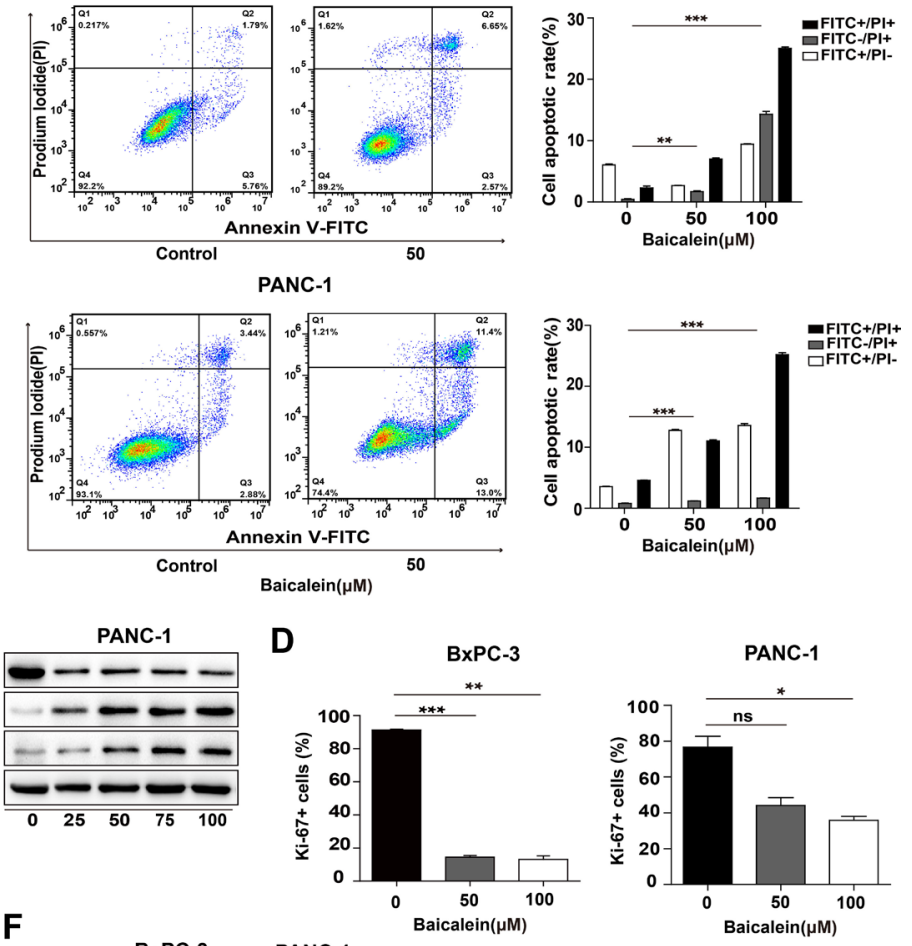

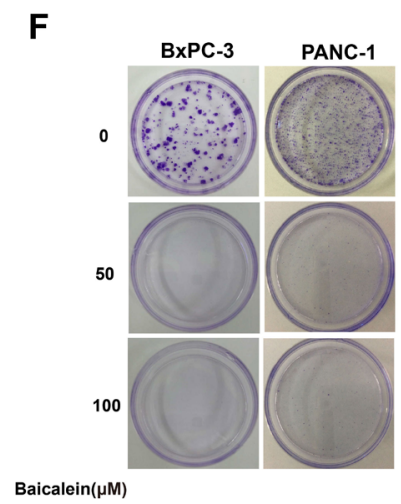

G
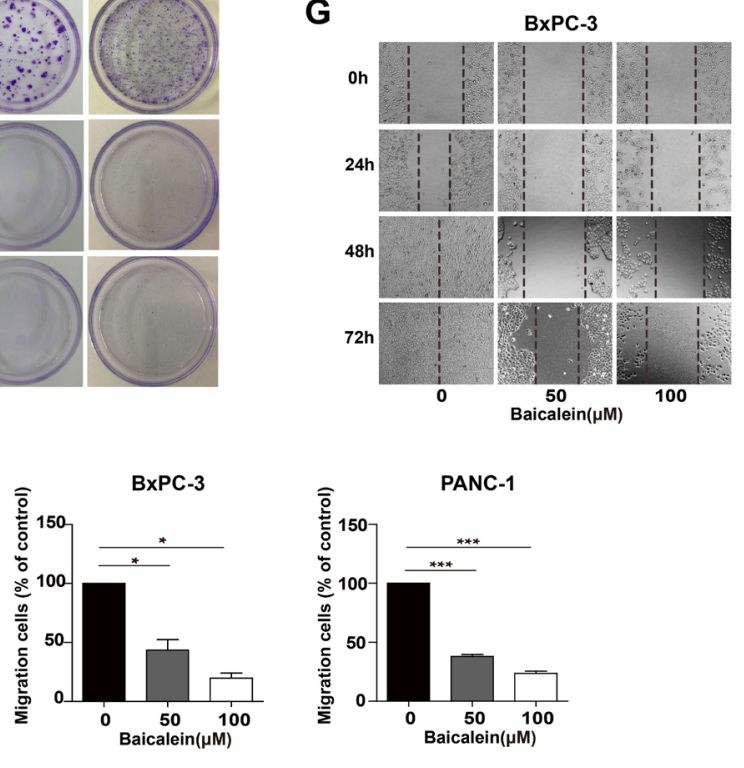

Figure 1: Effect of Baicalein on the viability and motility of pancreatic cancer cells. (A) Pancreatic cancer cell lines BxPC3 and PANC-1 were treated with increasing concentrations of Baicalein $(25,50,75$, and $100 \mu \mathrm{M})$. DMSO was used as control. Cell proliferation was measured by the CCK8 assay at $24 \mathrm{~h}, 48 \mathrm{~h}$, and $72 \mathrm{~h}$, respectively. (B) BxPC-3 and PANC-1 cells were treated with 50 or $100 \mu \mathrm{M}$ Baicalein for $48 \mathrm{~h}$, and then subjected to double staining with Annexin V-FITC and PI for flow cytometry detection. The percentages of $\mathrm{FITC}^{+}$and $\mathrm{PI}^{+}$cells were calculated by Flow Jo. (C) After BxPC-3 and PANC-1 cells were treated with different concentrations of Baicalein $(25,50,75$, and $100 \mu \mathrm{M}$, respectively) for $72 \mathrm{~h}$, the total proteins were extracted to detect the changes in the expression of Bcl-2, Bax and Caspase-9 by western blot, $\beta$-actin was used as an inner control. (D) After BxPC-3 and PANC-1 cells were treated with 50 or $100 \mu \mathrm{M}$ Baicalein for $48 \mathrm{~h}$, the proliferating cells were detected by Ki-67 immunofluoresence staining. The bar graphs represent the ratios of $\mathrm{Ki}-67^{+}$cells to total cells. (E) Cell cycle was analyzed by flow cytometry after PI staining. The bar graph represents the number of the cells in different phases. (F) BxPC-3 and PANC-1 were treated with 50 or $100 \mu \mathrm{M}$ Baicalein, respectively. After 2 weeks of continuous cultivation, colony forming ability was detected by crystal violet staining. (G) BxPC-3 cells were scratched before treatment with 50 or $100 \mu \mathrm{M}$ Baicalein, and then photographed at $24 \mathrm{~h}, 48 \mathrm{~h}$ and $72 \mathrm{~h}$, respectively. (H) Cell invasion ability was analyzed by the Transwell assay. The bar graph represents the number of the cells migrating to the bottom layer. ${ }^{*} p<0.05,{ }^{* *} p<0.01,{ }^{* * *} p<0.001$. 
indeed decreased the phosphorylation levels of Akt and ERK in a dose dependent manner (Figure 2A), especially the phosphorylation of Akt at Threonine 308 (T-308). Since the T-308 of Akt is mainly phosphorylated by PDK1, we further determined the expression of PDK1. As anticipated, Baicalein also reduced the level of PDK1 in BxPC-3 and PANC-1 cells (Figure 2A). To confirm the roles of $\mathrm{PI} 3 \mathrm{~K} / \mathrm{Akt}$ and $\mathrm{MEK} / \mathrm{ERK}$ pathways on pancreatic cancer cells, we treated BxPC-3 and PANC-1 cells with PI3K inhibitor LY294002 and MEK inhibitor PD98059, respectively. The CCK8 assay and wound healing assay showed that both inhibitors suppressed not only proliferation but also migration of pancreatic cancer cells (Supplementary Figure 2A and Figure 2B). Compared with PD98059, the inhibitory effects of LY294002 were more pronounced, suggesting that PI $3 \mathrm{~K} / \mathrm{Akt}$ activation is

\section{A}
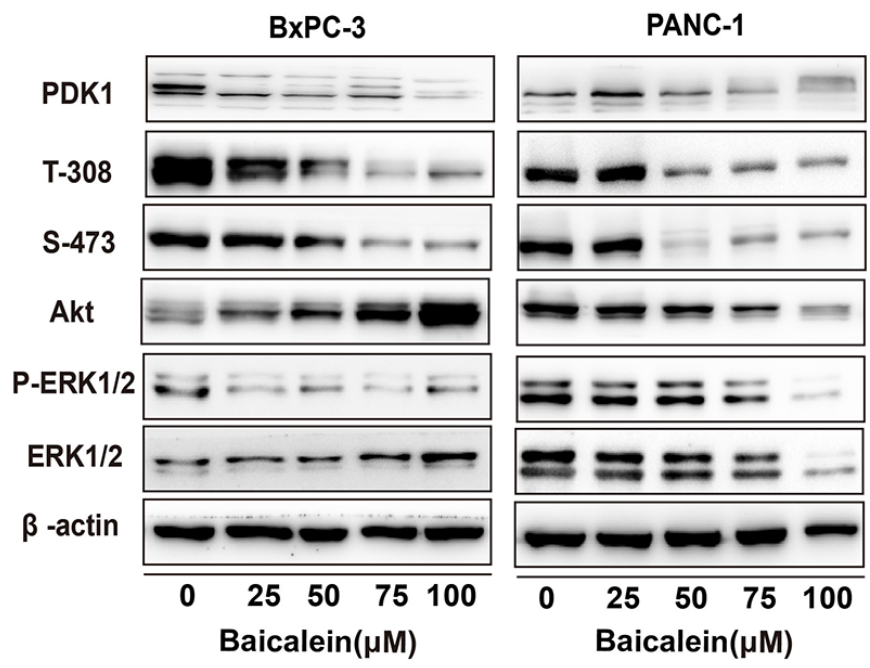

B
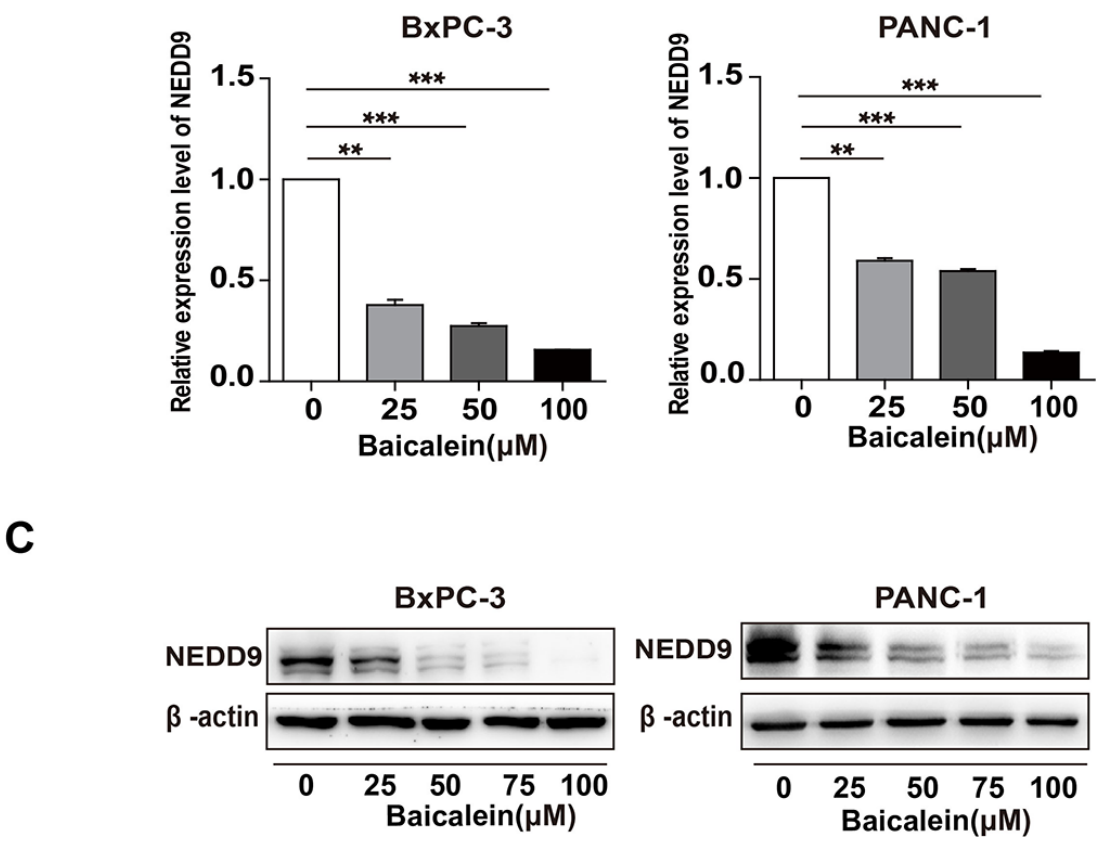

Figure 2: Effect of Baicalein on Akt and ERK1/2 phosphorylation and NEDD9 expression in pancreatic cancer cells. (A) After BxPC-3 and PANC-1 were treated with different concentrations of Baicalein $(25,50,75$, and $100 \mu \mathrm{M})$ for $72 \mathrm{~h}$, the protein levels of PDK1, Akt, and ERK1/2, as well as the phosphorylation levels of Akt on T-308 and S-473, and that of ERK1/2 (p-ERK1/2) were examined. $\beta$-actin was used as an inner control. (B) BxPC-3 and PANC-1 were treated with different concentrations of Baicalein $(25,50$, 75 , and $100 \mu \mathrm{M}$ ). DMSO was used as control. After treatment for $48 \mathrm{~h}$, the mRNA level of NEDD9 was detected by qRT-PCR. ** $p<0.01$, $* * * p<0.001$. (C) After treatment for $72 \mathrm{~h}$, the protein level of NEDD9 was detected by western blot. 
more important for pancreatic cancer cell development, which was further supported by the FACS results that LY294002 caused more remarkable apoptosis than PD98059 to BxPC-3 and PANC-1 cells (Supplementary Figure 2C).

Considering that NEDD9, which is involved in multiple Ras-related signalings including Akt and ERK, is highly expressed in pancreatic cancer tissues, we hypothesized that Baicalein may play a role on NEDD9 expression. Thus, we examined NEDD9 mRNA and protein levels in BxPC-3 and PANC-1 cells treated by Baicalein for $48 \mathrm{~h}$ and $72 \mathrm{~h}$. The results showed that in both cells, Baicalein considerably decreased not only the mRNA level of NEDD9 (Figure 2B), but also its protein level in a dose-dependent manner (Figure 2C).

\section{NEDD9 knockdown suppresses Akt and ERK signalings, also the expression of PDK1 in pancreatic cancer cells}

To determine the effects of NEDD9 on Akt and ERK signal pathways in pancreatic cancer cells, we blocked its expression by two synthesized NEDD9 siRNAs. As shown in Figure 3A, siNEDD9-2 efficiently knocked down NEDD9 expression in BxPC-3 and PANC-1 cells. The level of phosphorylated Akt (p-Akt) at T-308, but not at S-473, was decreased upon NEDD9 knockdown. The inhibitory effect was also observed on the phosphorylated ERK (Figure 3B).

Our previous results showed that Baicalein could suppress the expression of both NEDD9 and PDK1 and these two gene products locate upstream p-Akt T-308 $[30,38]$, whereas their relationship is unknown. The results showed that NEDD9 interference decreased, but NEDD9 overexpression increased PDK1 expression at both mRNA and protein levels (Figure 3C and 3D). These results indicate that, in pancreatic cancer cells, NEDD9 knockdown can inhibit Akt and ERK pathways, and also decrease p-Akt at T-308 through suppressing the expression of PDK1.

\section{NEDD9 knockdown inhibits pancreatic cancer cell malignancy}

Besides, upon NEDD9 interference, we also found that, compared with the negative control siNC, siNEDD9-2 significantly decreased cell viability and increased cell death at $72 \mathrm{~h}$ (Figure 4A). Ki-67 immunostaining showed that the proliferation of NEDD9 knockdown cells was obviously suppressed (Figure 4B and Supplementary Figure 3). Western blotting showed that the protein level of Bax was upregulated, while that of Bcl-2 was downregulated after transfection of siNEDD9-2 into BxPC-3 for $72 \mathrm{~h}$ (Figure 4C). Moreover, we also carried out wound healing assays to examine the effect of NEDD9 knockdown on cell mobility. As demonstrated in Figure 4D, there were only a few cells that migrated to the scratched area in NEDD9 knockdown groups. These results demonstrated that NEDD9 knockdown induced apoptosis of BxPC-3 and PANC-1 cells as well as decreased their proliferation and mobility, which is consistent with the anti-cancer effects of Baicalein.

\section{NEDD9 overexpression could rescue the phenotype of Baicalein-treated BxPC-3 and PANC-1 cells}

To explore the role of NEDD9 in the killing property of Baicalein on pancreatic cancer cells, we overepxressed NEDD9 in Baicalein-treated BxPC-3 or PANC-1 cells. The results showed that, with elevated expression of NEDD9, the proliferation of Baicaleintreated BxPC-3 or PANC-1 cells increased (Figure 5A), and the migration and invasion ability gradually enhanced as well (Figure 5B). In contrast, the percentages of apoptotic cells decreased, although the change was not statistically significant (Figure 5C). Moreover, NEDD9 overexpression could rescue Baicalein-decreased Akt phosphorylation at T-308, but not at S-473, and slightly increase ERK phosphorylation (Figure 5D). As expected, NEDD9 overexpression in Baicalein-treated BxPC-3 or PANC-1 cells also restored PDK1 expression (Figure 5D). Taken together, our data revealed that, in the presence of Baicalein, NEDD9 overexpression was able to reactivate Akt and ERK and rescue the phenotype involving proliferation, motility and apoptosis of pancreatic cancer cells, indicating that NEDD9 is a primary target of Baicalein in pancreatic cancer cells.

\section{DISCUSSION}

In this study, we demonstrated that Baicalein could effectively inhibit the proliferation, migration, and invasion of BxPC-3 and PANC-1 cells, as well as cause a massive cell death, which was achieved through suppressing the $\mathrm{PI} 3 \mathrm{~K} / \mathrm{Akt}$ and $\mathrm{MEK} / \mathrm{ERK}$ signaling activation in a dose- and time-dependent manner. Further, we discovered that Baicalein could decrease the expression of NEDD9, which was responsible for the inactivation of Akt and ERK by Baicalein treatment. Especially, Baicalein decreased Akt phosphorylation at T-308 via reducing NEDD9-dependent PDK1 expression (Figure 6). Indeed, overexpression of NEDD9 in BxPC-3 and PANC-1 cells treated with Baicalein could effectively rescue their proliferation and invasion.

Baicalein can promote pancreatic cancer cell apoptosis through up-regulating Bax and down-regulating Bcl-2 and Mcl-1, which has been reported by other groups $[14,15]$. Here we showed that a defined concentration 
A

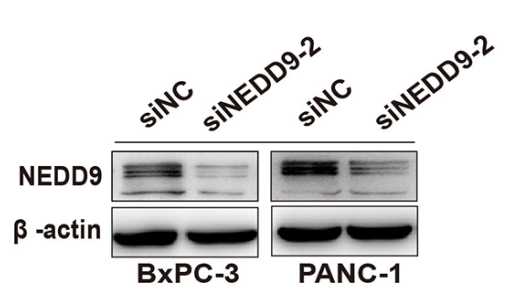

B

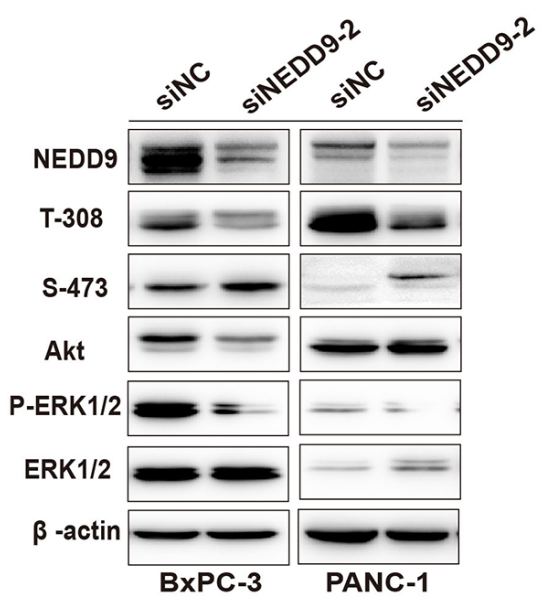

D

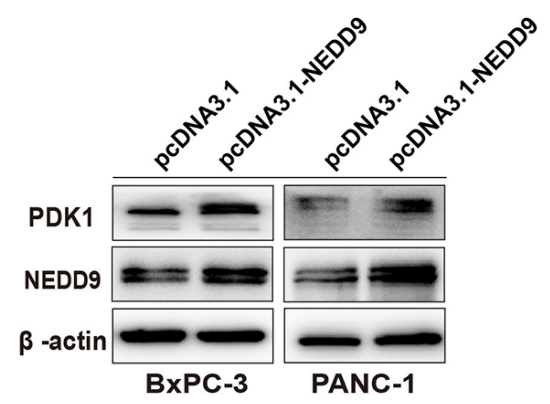

BXPC-3

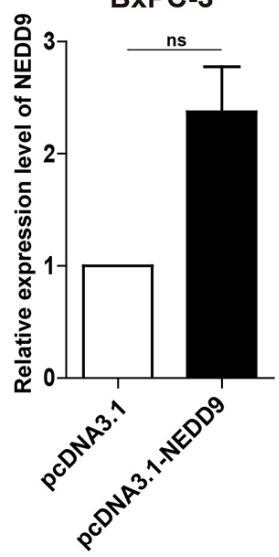

C
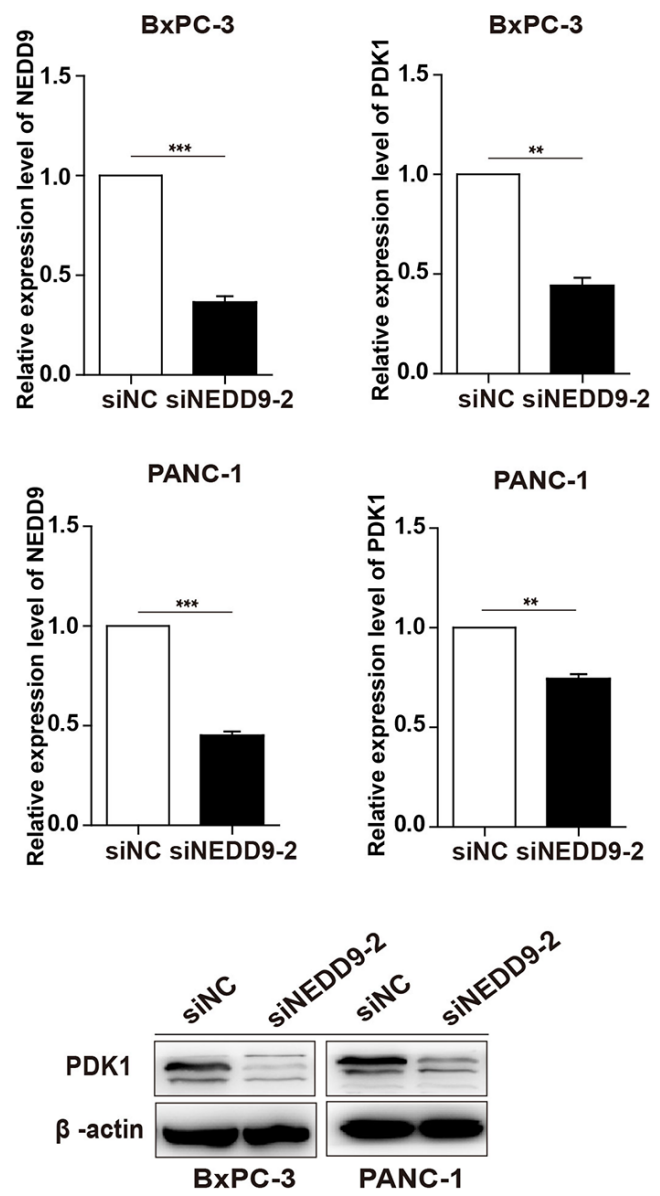

BxPC-3
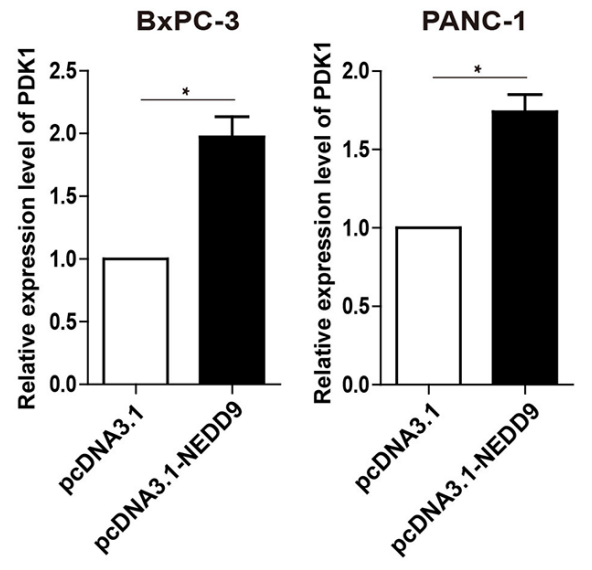

Figure 3: Effects of NEDD9 on phosphorylation of Akt and ERK1/2 and the expression of PDK1 in pancreatic cancer cells. (A) siNEDD9-2 could efficiently suppress NEDD9 expression in both cell lines. (B) After BxPC-3 or PANC-1 cells were transfected with $60 \mathrm{nM}$ siNC or siNEDD9-2 for $72 \mathrm{~h}$, the levels of p-Akt on T-308 and S-473, and p-ERK1/2 were detected. $\beta$-actin was used as a loading control. (C) After BxPC-3 or PANC-1 cells were transfected with $60 \mathrm{nM}$ siNC or siNEDD9-2 for $72 \mathrm{~h}$, the mRNA and protein levels of PDK1 were analyzed. $\beta$-actin was used as a loading control. **p $<0.01, * * * p<0.001$. (D) After BxPC-3 and PANC-1 cells were transfected with a full-length NEDD9 expression vector, the mRNA levels and proteins levels of PDK1 were analyzed. An empty vector acted as the control. ${ }^{*} \mathrm{p}<0.05$. 
of Baicalein not only promotes cell apoptosis, but also inhibits the proliferation, colony formation, migration, and invasion of pancreatic cancer cells. Notably, this chemical exhibits low toxicity to normal human cells. Actually, it has already been reported that Baicalein specifically repressed the growth of the cancer cells but not the normal cells, such as normal human fetal lung diploid cell line
TIG-1, normal human peripheral blood lymphocytes and normal rat hepatocytes [39-41]. Furthermore, Baicalein administration in vivo $(20 \mathrm{mg} / \mathrm{kg}$ /day p.o.) is able to retard the growth of xenografted prostate cancer cells by $55 \%$ as compared with placebo groups after transplantation for 2 weeks [42]; intraperitoneal injection of Baicalein (5, 10 , and $20 \mathrm{mg} / \mathrm{kg} /$ day; i.p.) can repress orthotopic glioma
A

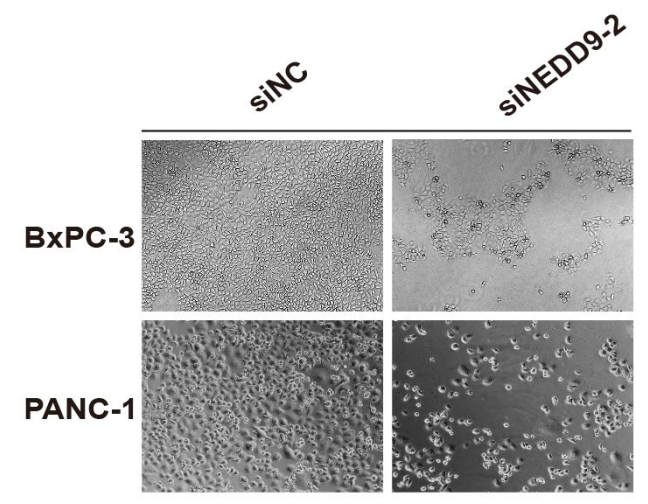

B

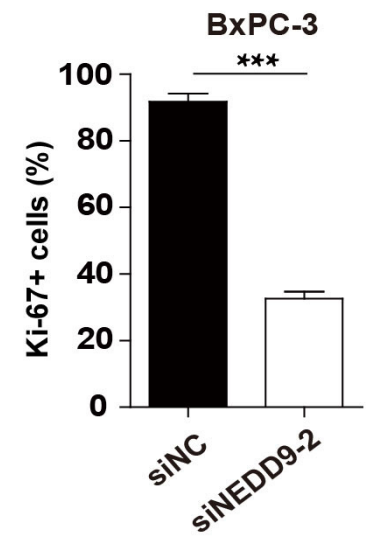

PANC-1

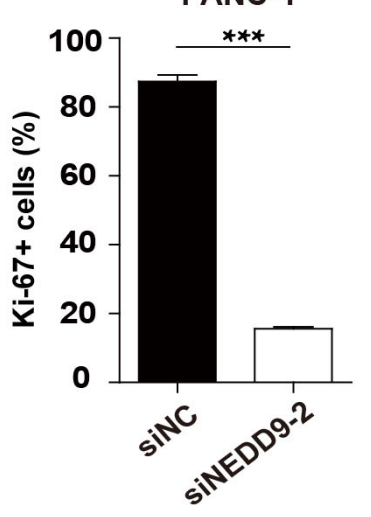

C

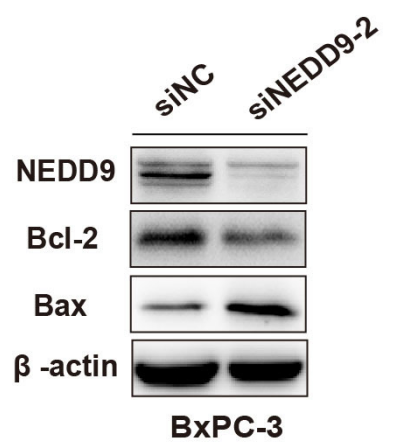

BXPC-3

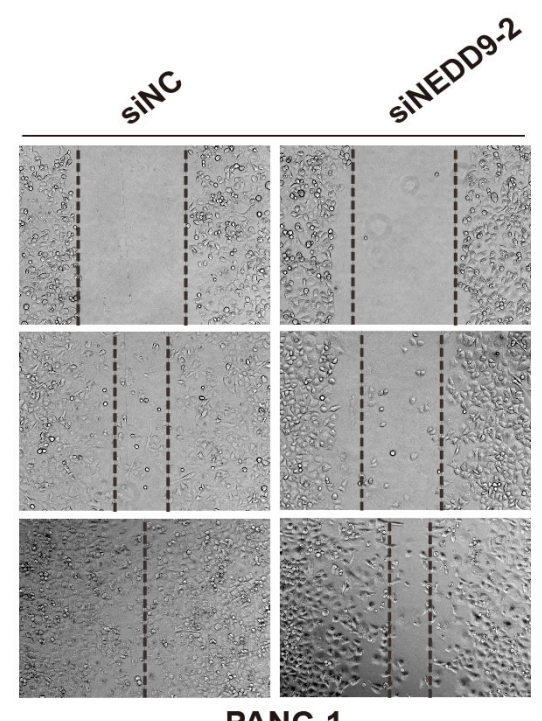

PANC-1

Figure 4: Effects of NEDD9 knockdown on pancreatic cancer cell progression. (A) $72 \mathrm{~h}$ post transfection, the cell morphology was photographed. (B) $48 \mathrm{~h}$ post transfection, cell proliferation was detected by Ki-67 immunofluoresence staining. The histograms represent the statistical results. ${ }^{* * *} p<0.001$. (C) The apoptosis-related protein Bcl-2 and Bax were examined. (D) The migration ability of NEDD9 knockdown cells was analyzed by the wound healing assay at $24 \mathrm{~h}, 48 \mathrm{~h}$ and $72 \mathrm{~h}$, respectively. 
and human hepatoma models and relieve edema [43, 44]. All these results suggest that Baicalein can be a potent therapeutic medicine on pancreatic cancer.

Our results also showed that Baicalein inhibits pancreatic cancer progression through inactivation of the PI3K/Akt and MEK/ERK signalings, which has been found to be highly active in pancreatic cancers [26]. The inactivation of the Akt and ERK signaling pathways by Baicalein is achieved through downregulation of NEDD9, which is consistent with the previous findings that NEDD9 knockout in a mouse breast cancer model decreases cell proliferation through inhibiting its direct partner FAK and Src, further lowering the Ras-related signaling Akt, ERK and SHCA [45]. However, what is different from the mammary tumor cells is that NEDD9 knockdown in pancreatic cancer cells mainly decrease phosphorlyation of Akt at T-308, but not at S-473. It has been found that AKT phosphorylation at S-473 and T-308 are not always
A

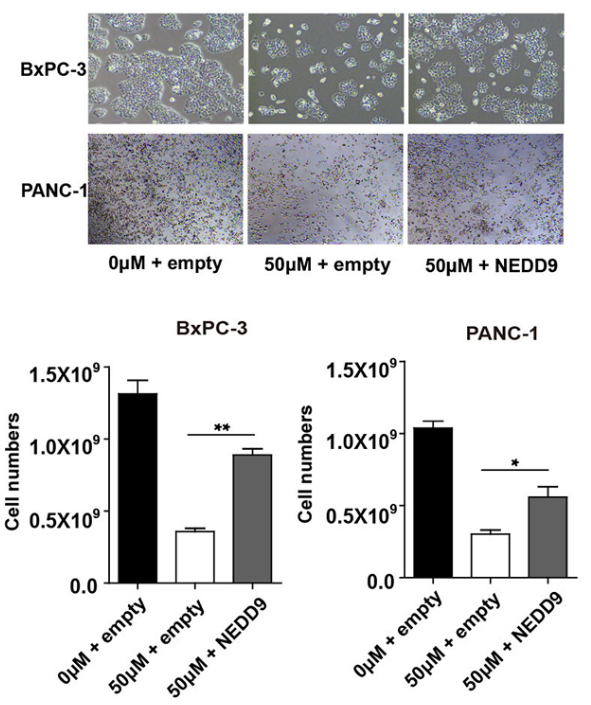

B
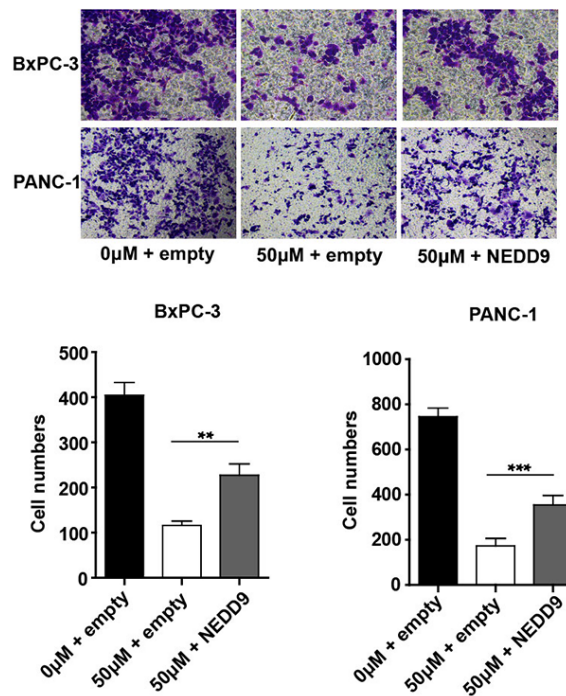

C
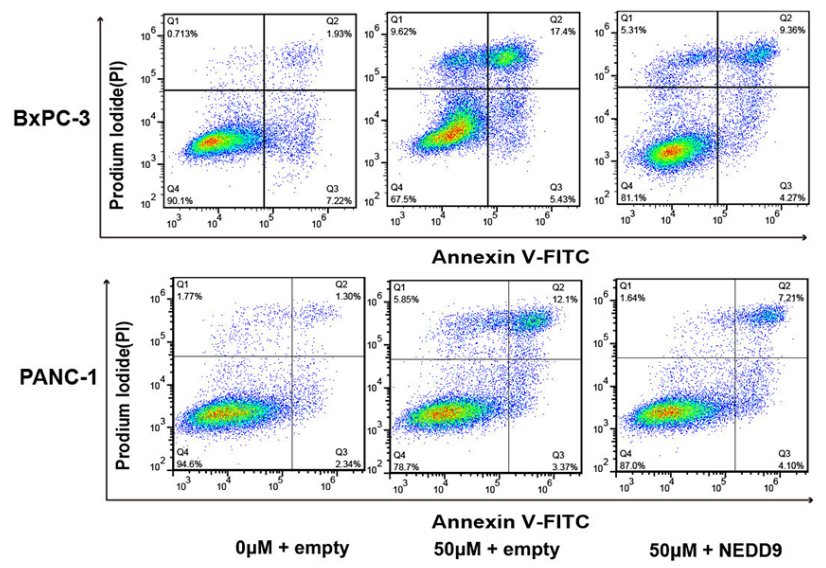

D
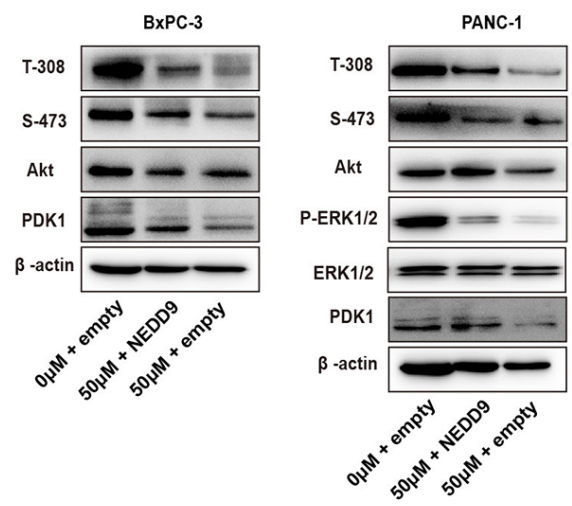

Figure 5: Effect of NEDD9 overexpression on Baicalein-treated pancreatic cancer cell growth and invasion. (A) After treated with $50 \mu \mathrm{M}$ Baicalein for $48 \mathrm{~h}, \mathrm{BxPC}-3$ and PANC-1 cells were transfected with the expression or empty vector for another $48 \mathrm{~h}$. The viable cells were counted, and the histograms represent the statistical results. (B) Cell migration was tested by the Transwell assay and the histograms represent the statistical results. (C) Cell apoptosis was studied by flow cytometry analysis of Annexin V-FITC and PI double staining. (D) After treated with $50 \mu \mathrm{M}$ Baicalein for $48 \mathrm{~h}, \mathrm{BxPC}-3$ and PANC-1 cells were transfected with the NEDD9 expression vector or empty vector for another $48 \mathrm{~h}$. The protein levels of PDK1, as well as the phosphorylation levels of Akt on T-308 and S-473 and ERK were examined. $* * p<0.01, * * * p<0.001$. 
well correlated [46-48], but the reasons are still unknown. Actually, Baicalein inhibits the phosphorylation of Akt at both T-308 and S-473. Our research firstly demonstrated that Baicalein decreased phosphorylation of Akt at T-308 through targeting NEDD9-dependent PDK1 expression, but the target of Baicalein on the suppression of p-AKT at S-473 in pancreatic cancer cells requires further exploration.

It should be pointed out that although Baicalein significantly decreases NEDD9 expression to repress Akt and ERK signalings, NEDD9 might not be a direct target of Baicalein in pancreatic cancer cells. It has been reported that, in breast cancer cells, Baicalein down-regulates Wnt/ $\beta$-catenin pathway to further inhibit breast cancer cell metastasis [49]. Besides, NEDD9 is demonstrated to be a direct target of $\mathrm{Wnt} / \beta$-catenin, since there is a TCF binding site on the promoter of NEDD9, which responds to Wnt3a, $\beta$-catenin, and Dvl2 in a dose-dependent manner [31]. Moreover, NEDD9 has been proved by CHIP-Seq to be a downstream target of TGF- $\beta$ signal pathway, whose activation increases NEDD9 expression and promotes cancer metastasis [50-52]. Molecular docking analysis has demonstrated that Baicalein could specifically bind to the ATP binding site of ALK5 (TGF- $\beta$ I type receptor) to repress its kinase activity. Thus, Baicalein may also decrease NEDD9 expression through repressing Wnt and/or TGF- $\beta$ signal pathway and then suppress its downstream Akt and/or ERK activation in pancreatic cancer cells.

In summary, we have identified NEDD9 as a novel target of Baicalein in two different types of pancreatic cancer cells. Through suppressing NEDD9 expression, Baicalein is able to inactivate the Akt and ERK cascades and thus effectively inhibit pancreatic cancer proliferation and invasion. Our findings suggest that Baicalein, with low toxicity to normal human cells, can be a potent remedy applied to pancreatic cancer treatment in the future.

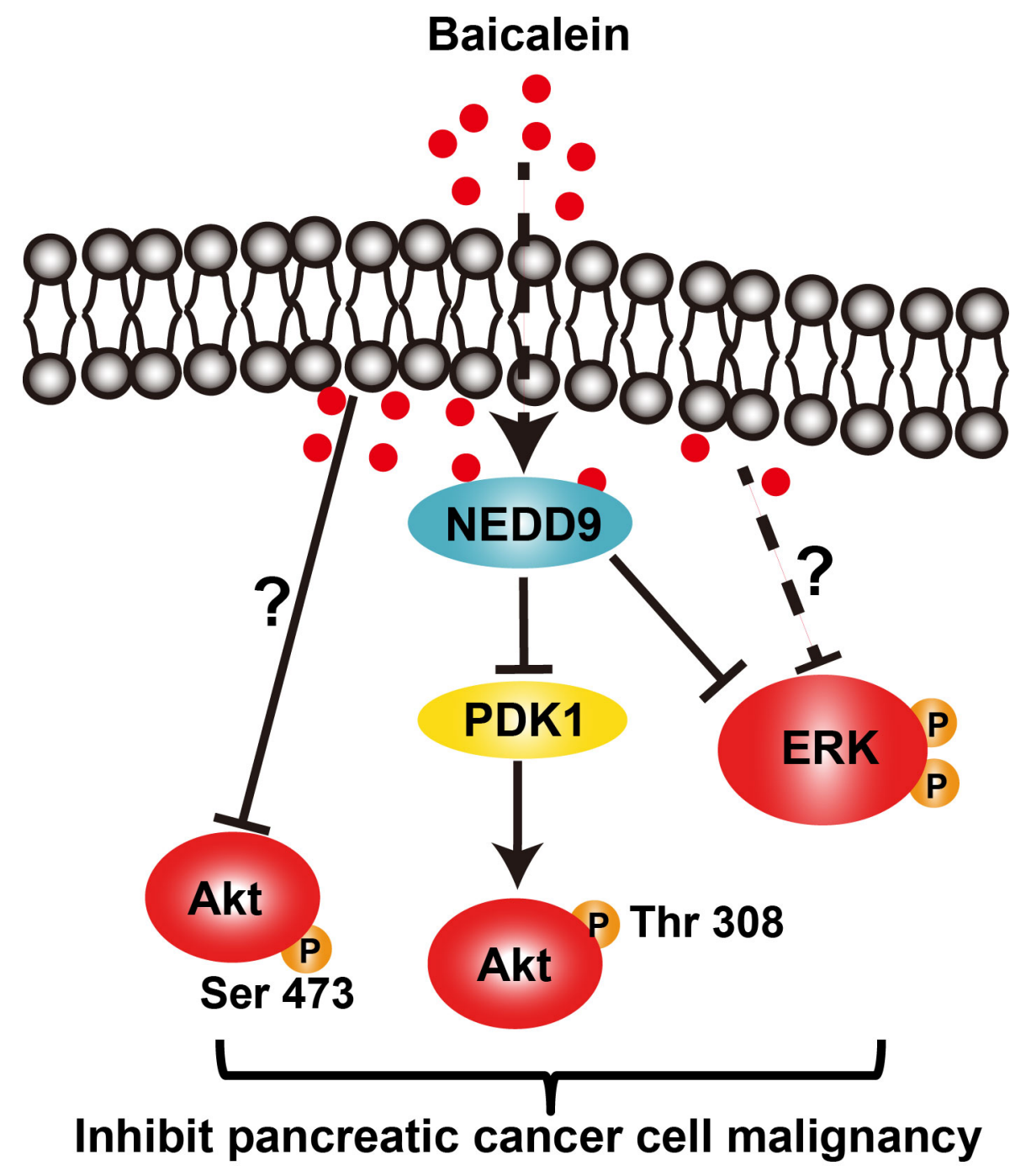

Figure 6: The schematic diagram of the signaling pathways affected by Baicalein in pancreatic cancer cells. 


\section{MATERIALS AND METHODS}

\section{Cell culture and reagents}

The human pancreatic cancer cell lines PANC-1, BxPC-3 and 293T were obtained from ATCC, the normal human cell lines HL-7702 cells was generous gifts by Professor GC Sui. The 293T cells were cultured in DMEM Medium with high glucose (Hyclone ${ }^{\mathrm{TM}}$ ) supplemented with $10 \%$ fetal bovine serum (FBS) (Biological Industries, 04-001-1A), 1\% glutamine (Hyclone ${ }^{\mathrm{TM}}$ ) and 1\% penicillin and streptomycin (Hyclone ${ }^{\mathrm{TM}}$ ). All other cells were grown in RPMI-1640 Medium (Hyclone ${ }^{\mathrm{TM}}$ ). Baicalein and inhibitors (LY2940042 and PD98059) were purchased from Sigma and dissolved in DMSO.

\section{Real-time qPCR}

The total RNA was extracted by Tripure ${ }^{\mathrm{TM}}$ reagent (Roche, USA) according to the manufacturer's protocol. Each sample was reversed to first strand cDNA using the All-in-One First-Stand Synthesis MasterMix (5X, with DNase I) (NOVA, Yugong Biolabs Inc, Jiangsu, China). All primers used were provided in Supplementary Table 1. The Faststart ${ }^{\mathbb{B}}$ Universal SYBR Green Master mix (Roche, Indianapolis, IN, USA) was used in real-time PCR carried out in the LightCycler ${ }^{\circledR}$ 480II Real-Time PCR System (Roche, Basel, Switzerland). Quantification was performed using the second derivative maximum method. mRNA expression levels were normalized to that of $\beta$-actin.

\section{Western blotting}

BxPC-3 and PANC-1 cells treated with Baicalein, inhibitors, or siRNAs were lysed in the RIPA buffer (Beyotime Biotechnology). The concentrations of the total proteins were measured using the Bicinchoninic acid (BCA) method (Beyotime Biotechnology). Protein samples $(20 \mu \mathrm{g})$ were subjected to SDSPAGE and transferred to nitrocellulose membranes by electroblotting. The membranes were incubated with the primary antibodies and then the corresponding secondary antibodies (horseradish peroxidase-conjugated goat anti-Rabbit IgG or goat anti-mouse IgG at 1:1000 dilution, Beyotime Biotechnology). The signals were detected using Super ECL Detection Reagent (Highsig ECL Western Blotting Substrate, 180-5001, Tanon, Shanghai, China). Primary antibodies used: NEDD9 (\#4044, 1:500), Akt (\#4691, 1:1000), p-Akt S-473 (\#4060, 1:1000), p-Akt T-308 (\#2965, 1:1000), ERK1/2 (\#9102, 1:1000), p-ERK1/2 (\#9101, 1:1000), PDK1(\#3062, 1:1000), P21(\#8831, 1:1000), P27(\#3686, 1:1000) and cleaved caspase-9 (\#7237, 1:1000) from Cell Signaling Technology Inc. (Danvers, MA, USA), Bax (AB026, 1:1000) and Bcl-2 (AB112, 1:1000) from Beyotime Biotechnology (Shanghai, China).

\section{Transient transfection}

The pancreatic cancer cells were respectively transfected with $60 \mathrm{nM}$ siNEDD9s and negative control siNC, using Lipofectamine ${ }^{\circledR}$ RNAiMAX (Thermo Fisher Scientific), while pcDNA3.1 plasmids with or without full-length NEDD9 were transfected using Lipofectamine $^{\circledR} 2000$ according to the manufacturer's instructions (Invitrogen, USA). siRNAs(GenePharma biological company) or plasmid sequences are available in Supplementary Table 2. The RNAi efficiency or gene overexpression was determined by Western blotting.

\section{CCK8 assay and cell counting}

To analyze cell viability, BxPC-3 and PANC-1 cells were seeded at a concentration of $8 \times 10^{3}$ per 96 -well. On the next day, cells were supplied with a fresh medium containing Baicalein, inhibitors, or DMSO (control) or transfected with siRNAs. After $24 \mathrm{~h}, 48 \mathrm{~h}$, and $72 \mathrm{~h}$ of cultivation, $10 \mu \mathrm{l}$ of the CCK8 reaction solution (Dojindo Laboratories, Japan) was added to each well. After $2-3 \mathrm{~h}$ incubation at $37^{\circ} \mathrm{C}$ in the $5 \% \mathrm{CO}_{2}$ incubator, the absorbance at $450 \mathrm{~nm}$ was measured by a microplate reader (Sunrise ${ }^{\mathrm{TM}}$, Tecan, Männedorf, Switzerland). Moreover, BxPC-3 and PANC-1 cells were transfected with the full-length NEDD9 expression vector. After treated with $50 \mu \mathrm{M}$ Baicalein for $48 \mathrm{~h}$, cell numbers were counted using an automated cell counter (LUNA ${ }^{\mathrm{TM}}$ Automated Cell Counter, Logos Biosystems, Korea).

\section{Colony formation assay}

BxPC-3 and PANC-1 cells were seeded in $60 \mathrm{~mm}$ dishes at a concentration of 1,000 cells per plate. The cells were treated with DMSO or Baicalein $(50$ or $100 \mu \mathrm{M})$, and then cultured for two weeks at $37^{\circ} \mathrm{C}$ in the $5 \% \mathrm{CO}_{2}$ incubator. All colonies were fixed in 4\% PFA for $20 \mathrm{~min}$, dried in air, and stained with $0.05 \%$ crystal violet.

\section{Cell-cycle analysis}

After BxPC-3 and PANC-1 cells were treated for 48 $\mathrm{h}$, the cells were collected and fixed with ice-cold $70 \%$ ethanol for $2 \mathrm{~h}$ at $4^{\circ} \mathrm{C}$. After centrifugation at $900 \mathrm{rpm}$ for $5 \mathrm{~min}$, the cells were washed and re-suspended in PBS containing propidium iodide (PI; $50 \mathrm{mg} / \mathrm{ml}$ ) and RNase-A $(50 \mu \mathrm{g} / \mathrm{ml})$. Samples were then incubated at room temperature for $30 \mathrm{~min}$ and analyzed by a flow cytometer (BD Accuri' ${ }^{\mathrm{TM}}$ C6 Plus, BD Biosciences, New York, USA). Cell-cycle phases were analyzed using Modfit ${ }^{\mathrm{TM}}$ Software.

\section{Apoptosis analysis by Annexin V- PI double staining}

Apoptosis was analyzed using the Annexin V-PI apoptosis detection kit (A211, Vazyme Biotech Co., Ltd, 
Nanjing, China). Briefly, the treated BxPC-3 and PANC-1 cells were trypsinized and washed twice with ice-cold PBS and re-suspended in the binding buffer at a concentration of $10^{5}$ per well in a total volume of $100 \mu 1$. Then, the cells were supplied with $5 \mu \mathrm{l}$ of Annexin V-FITC and $5 \mu \mathrm{l}$ of PI and incubated in dark at room temperature for $10 \mathrm{~min}$. After that, $200 \mu \mathrm{l}$ of binding buffer was added into each sample for flow cytometry analysis.

\section{Wound healing assay}

BxPC-3 and PANC-1 cells were trypsinized and seeded in a 24 -well plate at a concentration of $8 \times 10^{4}$ cells per well. After overnight incubation, the cell monolayers were scratched using a plastic tip across the plate. The wells were washed three times with PBS to make sure that no suspending cells existed in the wound areas. Subsequently, the cells were incubated in low-serum $(2 \%)$ medium with treatments and the wound images were taken as $0 \mathrm{~h}$. After $24 \mathrm{~h}, 48 \mathrm{~h}$, and $72 \mathrm{~h}$, wound healing pictures were taken.

\section{Cell invasion assay}

Cell invasion was tested using a transwell matrigel assay system (3422, Corning Incorporated, USA). The treated cells were seeded with serum-free DMEM medium into the upper layer polycarbonate membrane filter and $20 \%$ FBS was added to the bottom chambers. After $48 \mathrm{~h}$ or $72 \mathrm{~h}$, the cells on the upper layer were removed with a cotton swab, while the cells on the bottom of the filter were fixed with $4 \%$ PFA, stained with $0.05 \%$ crystal violet and counted.

\section{Immunofluorescence staining}

The cells were fixed in 4\% PFA for $20 \mathrm{~min}$, washed with PBS and permeabilized using $0.3 \%$ triton X-100 for $25 \mathrm{~min}$ at room temperature. Samples were blocked with $10 \%$ normal animal serum for $1 \mathrm{~h}$ and incubated with the primary antibody rabbit anti-Ki-67 (NCL-Ki67P, 1:200, Novocastra Laboratories Ltd., Newcastle upon Tyne, UK) for $1 \mathrm{~h}$. Then, cells were washed and incubated for $1 \mathrm{~h}$ with the secondary antibody Alexafluor 488 Goat Anti-Rabbit $\operatorname{IgG}(\mathrm{H}+\mathrm{L})(\mathrm{A} 0423)$ or Alexafluor 555 Donkey AntiRabbit $\operatorname{IgG}(\mathrm{H}+\mathrm{L})$ (A0453) from Beyotime (Shanghai, China) diluted at 1:1000. The nuclei were stained with Hoechst 33258 (C1017, Beyotime, China) and visualized using a Nikon invert fluorescent microscope. Images were analyzed using Image Pro Plus software.

\section{Statistical analysis}

Each experiment was repeated three times, and significance was determined with two-tailed Student's t-test or two-way ANOVA. Error bars represent \pm SEM. $p$-value lower than 0.05 was considered as significant. * $p$ $<0.05, * * p<0.01$, and $* * * p<0.001$.

\section{Author contributions}

Rong-Tao Zhou performed experiments, data analysis, and manuscript writting. Mei He participated in experiment design and contributed to the drafting and editing of the manuscript. Ze Yu participated in literature search. Yang Liang performed part of experiment management. Yuzhe Nie participated in manuscript editing. Sheng Tai gave suggestions for the experiment design. Chun-Bo Teng conceived and designed the paper, and supervised the writing, editing and proofreading of the manuscript. All authors have read and approved the final manuscript for publication.

\section{ACKNOWLEDGMENTS}

We greatly thank Professor Guangchao Sui for his generous gift of cell line HL-7702. This work was supported by the Fundamental Research Funds for the Central Universities (No. 2572016EAJ3) and the National Natural Science Foundation of China (No. 31472159).

\section{CONFLICTS OF INTEREST}

The authors declare no competing financial interest.

\section{REFERENCES}

1. Lin QJ, Yang F, Jin C, Fu DL. Current status and progress of pancreatic cancer in China. World J Gastroenterol. 2015; 21:7988-8003.

2. Li D, Xie K, Wolff R, Abbruzzese JL. Pancreatic cancer. Lancet. 2004; 363:1049-1057.

3. Hidalgo M. Pancreatic cancer. N Engl J Med. 2010; 362:1605-1617.

4. Borazanci E, Von Hoff DD. Nab-paclitaxel and gemcitabine for the treatment of patients with metastatic pancreatic cancer. Expert Rev Gastroenterol Hepatol. 2014; 8:739-747.

5. Martin J, Dusek J. [The Baikal scullcap (Scutellaria baicalensis Georgi) - a potential source of new drugs]. [Article in Czech]. Ceska Slov Farm. 2002; 51:277-283.

6. Li-Weber M. New therapeutic aspects of flavones: the anticancer properties of Scutellaria and its main active constituents Wogonin, Baicalein and Baicalin. Cancer Treat Rev. 2009; 35:57-68.

7. Huang Y, Tsang SY, Yao X, Chen ZY. Biological properties of baicalein in cardiovascular system. Curr Drug Targets Cardiovasc Haematol Disord. 2005; 5:177-184.

8. Kim KH, Park YD, Park H, Moon KO, Ha KT, Baek NI, Park CS, Joo M, Cha J. Synthesis and biological evaluation of a novel Baicalein glycoside as an anti-inflammatory agent. Eur J Pharmacol. 2014; 744:147-156. 
9. Liu H, Dong Y, Gao Y, Du Z, Wang Y, Cheng P, Chen A, Huang $H$. The fascinating effects of baicalein on cancer: a review. Int J Mol Sci. 2016; 17:e1681.

10. Lee JH, Li YC, Ip SW, Hsu SC, Chang NW, Tang NY, $\mathrm{Yu}$ CS, Chou ST, Lin SS, Lino CC. The role of $\mathrm{Ca}^{2+}$ in baicalein-induced apoptosis in human breast MDA-MB-231 cancer cells through mitochondria- and caspase-3dependent pathway. Anticancer Res. 2008; 28:1701-1711.

11. Ikemoto S, Sugimura K, Yoshida N, Yasumoto R, Wada $\mathrm{S}$, Yamamoto K, Kishimoto T. Antitumor effects of Scutellariae radix and its components baicalein, baicalin, and wogonin on bladder cancer cell lines. Urology. 2000; 55:951-955.

12. Miocinovic R, McCabe NP, Keck RW, Jankun J, Hampton JA, Selman SH. In vivo and in vitro effect of baicalein on human prostate cancer cells. Int J Oncol. 2005; 26:241-246.

13. Chen J, Li Z, Chen AY, Ye X, Luo H, Rankin GO, Chen YC. Inhibitory effect of baicalin and baicalein on ovarian cancer cells. Int J Mol Sci. 2013; 14:6012-6025.

14. Takahashi H, Chen MC, Pham H, Angst E, King JC, Park J, Brovman EY, Ishiguro H, Harris DM, Reber HA, Hines OJ, Gukovskaya AS, Go VL.Baicalein, a component of Scutellaria baicalensis, induces apoptosis by Mcl-1 downregulation in human pancreatic cancer cells. Biochim Biophys Acta. 2011; 1813:1465-1474.

15. Tong WG, Ding XZ, Witt RC, Adrian TE. Lipoxygenase inhibitors attenuate growth of human pancreatic cancer xenografts and induce apoptosis through the mitochondrial pathway. Mol Cancer Ther. 2002; 1:929-935.

16. Donald G, Hertzer K, Eibl G. Baicalein - an intriguing therapeutic phytochemical in pancreatic cancer. Curr Drug Targets. 2012; 13:1772-1776.

17. Guo Z, Hu X, Xing Z, Xing R, Lv R, Cheng X, Su J, Zhou Z, Xu Z, Nilsson S, Liu Z. Baicalein inhibits prostate cancer cell growth and metastasis via the caveolin-1/Akt/mTOR pathway. Mol Cell Biochem. 2015; 406:111-119.

18. Agarwal S, Achari C, Praveen D, Roy KR, Reddy GV, Reddanna P. Inhibition of 12-LOX and COX-2 reduces the proliferation of human epidermoid carcinoma cells (A431) by modulating the ERK and PI3K-Akt signalling pathways. Exp Dermatol. 2009; 18:939-946.

19. Mammucari C, Schiaffino S, Sandri M. Downstream of Akt: FoxO3 and mTOR in the regulation of autophagy in skeletal muscle. Autophagy. 2008; 4:524-526.

20. Wang F, Wang Q, Zhou ZW, Yu SN, Pan ST, He ZX, Zhang X, Wang D, Yang YX, Yang T. Plumbagin induces cell cycle arrest and autophagy and suppressesepithelial to mesenchymal transition involving PI3K/Akt/mTORmediated pathway in human pancreatic cancer cells. Drug Des Devel Ther. 2015; 9:537-560.

21. Missiaglia E, Dalai I, Barbi S, Beghelli S, Falconi M, della Peruta M, Piemonti L, Capurso G, Di Florio A, delle Fave G, Pederzoli P, Croce CM, Scarpa A. Pancreatic endocrine tumors: expression profiling evidences a role for AKTmTOR pathway. J Clin Oncol. 2010; 28:245-255.

22. Gao N, Flynn DC, Zhang Z, Zhong XS, Walker V, Liu KJ, Shi X, Jiang BH. G1 cell cycle progression and the expression of G1 cyclins are regulated by $\mathrm{PI} 3 \mathrm{~K} / \mathrm{AKT} /$ $\mathrm{mTOR} / \mathrm{p} 70 \mathrm{~S} 6 \mathrm{~K} 1$ signaling in human ovarian cancer cells. Am J Physiol Cell Physiol. 2004; 287:C281-291.

23. Zhong J, Gencay MM, Bubendorf L, Burgess JK, Parson H, Robinson BW, Tamm M, Black JL, Roth M. ERK1/2 and p38 MAP kinase control MMP-2, MT1-MMP, and TIMP action and affect cell migration: a comparison between mesothelioma and mesothelial cells. J Cell Physiol. 2006; 207:540-552.

24. Sounni NE, Rozanov DV, Remacle AG, Golubkov VS, Noel A, Strongin AY. Timp-2 binding with cellular MT1-MMP stimulates invasion-promoting MEK/ERK signaling in cancer cells. Int J Cancer. 2010; 126:1067-1078.

25. Zhang ZN, Lv JR, Lei XM, Li SY, Zhang Y, Meng LH, Xue $\mathrm{RL}, \mathrm{Li} \mathrm{ZF}$. Baicalein reduces the invasion of glioma cells via reducing the activity of p38 signaling pathway. PLoS One. 2014; 9:e90318.

26. Kim SD, Lee YJ, Baik JS, Han JY, Lee CG, Heo K, Park YS, Kim JS, Ji HD, Park SI, Rhee MH, Yang K. Baicalein inhibits agonist- and tumor cell-induced platelet aggregation while suppressing pulmonary tumor metastasis via cAMPmediated VASP phosphorylation along with impaired MAPKs and PI3K-Akt activation. Biochem Pharmacol. 2014; 92:251-265.

27. Zhang HB, Lu P, Guo QY, Zhang ZH, Meng XY. Baicalein induces apoptosis in esophageal squamous cell carcinoma cells through modulation of the PI3K/Akt pathway. Oncol Lett. 2013; 5:722-728.

28. Sima N, Cheng X, Ye F, Ma D, Xie X, Lu W. The overexpression of scaffolding protein NEDD9 promotes migration and invasion in cervical cancer via tyrosine phosphorylated FAK and SRC. PLoS One. 2013; 8:e74594.

29. Shagisultanova E, Gaponova AV, Gabbasov R, Nicolas E, Golemis EA. Preclinical and clinical studies of the NEDD9 scaffold protein in cancer and other diseases. Gene. 2015; 567:1-11.

30. Iida J, Dorchak J, Clancy R, Slavik J, Ellsworth R, Katagiri Y, Pugacheva EN, van Kuppevelt TH, Mural RJ, Cutler ML, Shriver CD. Role for chondroitin sulfate glycosaminoglycan in NEDD9-mediated breast cancer cell growth. Exp Cell Res. 2015; 330:358-370.

31. Li Y, Bavarva JH, Wang Z, Guo J, Qian C, Thibodeau SN, Golemis EA, Liu W. HEF1, a novel target of Wnt signaling, promotes colonic cell migration and cancer progression. Oncogene. 2011; 30:2633-2643.

32. Kong C, Wang C, Wang L, Ma M, Niu C, Sun X, Du J, Dong Z, Zhu S, Lu J, Huang B. NEDD9 is a positive regulator of epithelial-mesenchymal transition and promotes invasion in aggressive breast cancer. PLoS One. 2011; 6:e22666. 
33. Jin Y, Li F, Zheng C, Wang Y, Fang Z, Guo C, Wang X, Liu H, Deng L, Li C. NEDD9 promotes lung cancer metastasis through epithelial-mesenchymal transition. Int J Cancer. 2014; 134:2294-2304.

34. Han T, Yi XP, Liu B, Ke MJ, Li YX.MicroRNA-145 suppresses cell proliferation, invasion and migration in pancreatic cancer cells by targeting NEDD9. Mol Med Rep. 2015; 11:4115-4120.

35. Xue YZ, Sheng YY, Liu ZL, Wei ZQ, Cao HY, Wu YM, $\mathrm{Lu}$ YF, Yu LH, Li JP, Li ZS. Expression of NEDD9 in pancreatic ductal adenocarcinoma and its clinical significance. Tumour Biol. 2013; 34:895-899.

36. Zhang Y, Yan W, Collins MA, Bednar F, Rakshit S, Zetter BR, Stanger BZ, Chung I, Rhim AD, di Magliano MP. Interleukin-6 is required for pancreatic cancer progression by promoting MAPK signaling activation and oxidative stress resistance. Cancer Res. 2013; 73:6359-6374.

37. El-Rayes BF, Ali S, Ali IF, Philip PA, Abbruzzese J, Sarkar FH. Potentiation of the effect of erlotinib by genistein in pancreatic cancer: the role of Akt and nuclear factorkappaB. Cancer Res. 2006; 66:10553-10559.

38. Alessi DR, Deak M, Casamayor A, Caudwell FB, Morrice N, Norman DG, Gaffney P, Reese CB, MacDougall CN, Harbison D, Ashworth A, Bownes M. 3 Phosphoinositidedependent protein kinase-1 (PDK1): structural and functional homology with the Drosophila DSTPK61 kinase. Curr Biol. 1997; 7:776-789.

39. Himeji M, Ohtsuki T, Fukazawa H, Tanaka M, Yazaki S, Ui S, Nishio K, Yamamoto H, Tasaka K, Mimura A. Difference of growth-inhibitory effect of Scutellaria baicalensisproducing flavonoid wogonin among human cancer cells and normal diploid cell. Cancer Lett. 2007; 245:269-274.

40. Hwang JM, Tseng TH, Tsai YY, Lee HJ, Chou FP, Wang CJ, Chu CY. Protective effects of baicalein on tert-butyl hydroperoxide-induced hepatic toxicity in rat hepatocytes. J Biomed Sci. 2005; 12:389-397.

41. Chen CH, Huang TS, Wong CH, Hong CL, Tsai YH, Liang CC, Lu FJ, Chang WH. Synergistic anti-cancer effect of baicalein and silymarin on human hepatoma HepG2 Cells. Food Chem Toxicol. 2009; 47:638-644.

42. Melisi D, Caputo R, Damiano V, Bianco R, Veneziani BM, Bianco AR, De Placido S, Ciardiello F, Tortora G. Zoledronic acid cooperates with a cyclooxygenase-2 inhibitor and gefitinib in inhibiting breast and prostate cancer. Endocr Relat Cancer. 2005; 12:1051-1058.

43. Wang FR, Jiang YS. Effect of treatment with baicalein on the intracerebral tumor growth and survival of orthotopic glioma models. J Neurooncol. 2015; 124:5-11.
44. Peng Y, Li QW, Li K, Zhao HW, Han ZS, Li FL, Sun M, Zhang YX. Antitumor activity of baicalein on the mice bearing U14 cervical cancer. Afr J Biotechnol. 2011; 10:14169-14176.

45. LzumchenkoE, Singh MK, Plotnikova OV, Tikhmyanova N, Little JL, Serebriiskii IG, Seo S, Kurokawa M, Egleston BL, Klein-Szanto A, Pugacheva EN, Hardy RR, Wolfson M. NEDD9 promotes oncogenic signaling in mammary tumor development. Cancer Res. 2009; 69:7198-7206.

46. Wan X, Helman LJ. Levels of PTEN protein modulate Akt phosphorylation on serine 473, but not on threonine 308 , in IGF-II-overexpressing rhabdomyosarcomas cells. Oncogene. 2003; 22:8205-8211.

47. Khor TO, Gul YA, Ithnin H, Seow HF. Positive correlation between overexpression of phospho-BAD with phosphorylated Akt at serine 473 but not threonine 308 in colorectal carcinoma. Cancer Lett. 2004; 210:139-150.

48. Tsurutani J, Fukuoka J, Tsurutani H, Shih JH, Hewitt SM, Travis WD, Jen J, Dennis PA. Evaluation of two phosphorylation sites improves the prognostic significance of Akt activation in non-small-cell lung cancer tumors. J Clin Oncol. 2006; 24:306-314.

49. Ma X, Yan W, Dai Z, Gao X, Ma Y, Xu Q, Jiang J, Zhang $\mathrm{S}$. Baicalein suppresses metastasis of breast cancer cells by inhibiting EMT via downregulation of SATB1 and Wnt/beta-catenin pathway. Drug Des Devel Ther. 2016; 10:1419-1441.

50. Vogel T, Ahrens S, Büttner N, Krieglstein K. Transforming growth factor beta promotes neuronal cell fate of mouse cortical and hippocampal progenitors in vitro and in vivo: identification of NEDD9 as an essential signaling component. Cereb Cortex. 2010; 20:661-671.

51. Omata Y, Nakamura S, Koyama T, Yasui T, Hirose J, Izawa N, MatsuMoto T, Imai Y, Seo S, Kurokawa M, TsutsuMi S, Kadono Y, Morimoto C. Identification of NEDD9 as a TGFbeta-Smad2/3 target gene involved in RANKL-induced osteoclastogenesis by comprehensive analysis. PLoS One. 2016; 11:e0157992.

52. Morimoto K, Tanaka T, Nitta Y, Ohnishi K, Kawashima H, Nakatani T.NEDD9 crucially regulates TGF-betatriggered epithelial-mesenchymal transition and cell invasion in prostate cancer cells: involvement in cancer progressiveness. Prostate. 2014; 74:901-910. 